\title{
Nutritional value of sugars and related compounds undigested in the small gut
}

\author{
By H. S. Wiggins, Dunn Clinical Nutrition Centre, Addenbrooke's Hospital, \\ Trumpington Street, Cambridge $C B 2$ I $Q E$
}

Little attention has been paid to the nutritional value per se of non-absorbed oligosaccharides found in the diet. More interest has been shown in the effects these compounds have on bowel function and on nitrogen metabolism in severe liver disease. This report examines some of those studies that seem particularly relevant to the nutritional importance of non-absorbed oligosaccharides.

The principal naturally-occurring non-absorbed sugars in a normal diet are lactose, raffinose, stachyose, and verbascose. In addition the semi-synthetic disaccharide lactulose is used in medicine and small amounts of lactulose may also occur in heat-processed milk products. The sugar alcohols, sorbitol and xylitol, are used as sweeteners in foods for diabetics and slimmers. Mannitol is used therapeutically as an osmotically-active agent in solutions used for transintestinal washouts and when given intravenously it acts as a diuretic. Both these uses result from the slow rate at which it passes across the membrane of the small intestinal or renal tubular cell. The small bowel mucosa is relatively impermeable to highly water-soluble compounds of the size of monosaccharides unless a special mechanism exists to facilitate their absorption. Such mechanisms exist for the absorption of glucose, galactose and fructose but only small amounts of other mono- or oligosaccharides can penetrate the mucosa (Holdsworth \& Dawson, 1965). Starch and sucrose are well absorbed if their constituent monosaccharides are released by pancreatic amylase or brush-border glycosidases. In the Western world lactose makes a significant contribution to carbohydrate consumption. This is only possible because uniquely amongst the primates and other mammals, most Western European, North American and Australian adults retain the newborn's ability to hydrolyse lactose to glucose and galactose. However, for most populations of the world the absence of lactase in the brush-border is the normal condition. In health less than $\mathrm{r} \%$ of the oligosaccharides are absorbed and when given parenterally, recovery in the urine is virtually complete (Wheeler et al. 1978). They are, therefore, unlikely to have any direct nutritional significance. A rather greater proportion of sorbitol, mannitol (Nasrullah \& Iber, 1969) and xylitol (Asano et al. 1972) are absorbed but whereas there is a virtually quantitative recovery of mannitol in the urine, sorbitol and xylitol enter into the normal carbohydrate metabolism of the mammalian organism (Tauster, 1974). The nutritional effects of that portion of the ingested materials that are not absorbed need further consideration. All these compounds, sugars and alcohols, which may be referred to 
collectively as non-absorbed sugars (NAS), possess two properties that mediate their behaviour in the alimentary tract and thus affect nutrition. First, they are water-soluble compounds of low molecular weight and so their solutions have high osmotic pressures. Second, they are all readily metabolized by intestinal bacteria.

\section{Small intestine}

In the small intestine bacterial activity is not usually a significant factor and therefore it is the osmotic effects of these sugars that might be expected to influence the absorption of nutrients. Normally the fluxes of water across the intestinal mucosa are adjusted to maintain isotonicity and there is net absorption of water as electrolytes, sugars and peptides are absorbed (Fordtran \& Locklear, I 966). The presence of unabsorbable molecules of low molecular weight results in the retention of fluid in the small intestine. The volumes of fluid are greater than would be expected from a knowledge of the amount and molecular weight of the compound. Bond \& Levitt (1976a) found that only one-third of the osmotic activity of terminal ileal fluid was accounted for by lactose in lactose malabsorbers. Davis et al. (1980) developed a solution to irrigate the whole intestine with minimum absorption of water and electrolytes. It contained $80 \mathrm{~mm}$-mannitol and $40 \mathrm{~mm}$-sulphate, a similar concentration of non-absorbable osmotically-active materials to the one Bond \& Levitt (1976a) had found. Thus, there is a requirement for certain concentrations of physiological electrolytes in intestinal juice. Because of this amplifying effect, $10 \mathrm{~g}$ lactulose $(29.3 \mathrm{mmol})$ would result in an increased volume of $250 \mathrm{ml}$ with a consequent increase in flow-rate in the small intestine. There is some evidence that this may affect the absorption of nutrients from the small bowel. When, in an intestinal perfusion study of absorption in children (Launiala, 1969), $150 \mathrm{~mm}$-glucose was replaced by an equivalent concentration of mannitol the flow-rate at the distal site was increased by $350 \%$. The absorption of xylose and palmitic acid were decreased by $40 \%$ but that of arginine by only $10 \%$. In another study a baby that was unable to absorb sucrose was found to have gross steatorrhoea when sucrose was included in the diet (Anderson et al. 1963). However, a much milder extent of malabsorption was found in lactase-deficient adults when lactose was included in a test meal (Debongnie et al. 1979). The osmotic effect of NAS in the small intestine can thus cause an increase in material entering the colon in addition to their own contribution. This is unlikely to be nutritionally significant in adults for those nutrients for which there is a large reserve of absorptive capacity.

Other osmotic effects in the small intestine have been described. Goldberg $e t$ al. ( 1980 ) have shown an augmentation of insulin release in response to intravenous glucose when $500 \mathrm{ml}$ mannitol $\left(45^{6} \mathrm{mosmol} / \mathrm{l}\right)$ is given by mouth. Hyperosmolar solutions also increase intestinal permeability to NAS (Menzies, r 974).

\section{Large intestine}

The presence of NAS in the diet will increase the load of water and electrolytes in the large intestine. Debongnie \& Phillips (1978) have shown, by experiments 
in which isotonic electrolyte solutions were instilled continuously into the human caecum, that the colon can absorb an extra load of at least $2 \mathrm{l} / \mathrm{d}$ and keep the faecal output down to a weight of less than $200 \mathrm{~g} / \mathrm{d}$. It would require $120 \mathrm{~g}$ raffinose or $80 \mathrm{~g}$ lactulose or lactose/d to cause an increase of this magnitude in ileal fluid entering the colon. Doses of lactulose of from 30 to $50 \mathrm{~g} / \mathrm{d}$ can cause an increased faecal output of $100 \mathrm{~g} / \mathrm{d}$ (Agostini et al. 1972). Some light has been thrown on the colonic effects of NAS in experiments in which dose-response curves were obtained for mannitol, lactulose, raffinose and magnesium sulphate (Saunders \& Wiggins, I $98 \mathrm{I}$ ). The faecal water output in the subsequent $48 \mathrm{~h}$ was used as the response. Increasing doses of the test substance, dissolved in water, were given to the fasting subjects. Polyethylene glycol (molecular weight $4000 ; 3 \mathrm{~g}$ ) was included in the dose to act as a recovery marker. Volatile fatty acids (VFA), chloride and soluble carbohydrate were measured in faecal water. It was found that whereas with $\mathrm{MgSO}_{4}$ there was an immediate response, for the NAS there was a lag period. The threshold for the response differed in different individuals. One subject tolerated a maximum dose of $73 \mathrm{mmol}$ lactulose whereas another tolerated $146 \mathrm{mmol}$ before faecal water output rose above $400 \mathrm{ml} / 48 \mathrm{~h}$. Similarly, doses of 120 and $357 \mathrm{mmol}$ mannitol were tolerated by different subjects. There was little change in the composition of the stools when no response in faecal water had occurred and, in particular, little soluble carbohydrate was found in these specimens. The expected products of bacterial metabolism of these compounds would be hydrogen, carbon dioxide and VFA. In the subjects with no change in faecal water output there was no increase in VFA output. Under these conditions NAS are probably fermented by the large bowel microflora and absorbed by the colon as VFA and thus are available to the host. When an increase in faecal water occurred after feeding lactulose or raffinose, all the expected sugars that could result from the hydrolysis of the oligosaccharide were found in the faecal water as well as the original compound (Table I). However, the total soluble carbohydrate recovered was less than that given and the increase in VFA excretion was less than might be calculated assuming I $7 \mathrm{~mol} \mathrm{VFA} / \mathrm{mol}$ hexose fermented (Hungate, 1966). In this case also, some VFA absorption is likely and so some of the NAS energy becomes available to the host.

A more detailed study of the fate of sugars in the colon has been made by Bond \& Levitt $(1976 b)$. [U- $\left.{ }^{14} \mathrm{C}\right]$ glucose was introduced into the colon of conventional rats, germ-free rats and human volunteers. Respiratory $\mathrm{CO}_{2}$ and faeces were collected and assayed for ${ }^{14} \mathrm{C}$. The major part of the radioactivity recovered from conventional rats was in the breath ( $43 \%$ of the dose). Of the $18 \%$ found in the faeces only $15 \%$ was dialysable. Insufficient oxygen was available in the colon to account for the production of all the ${ }^{14} \mathrm{CO}_{2}$ by oxidative metabolism of colonic organisms and a similar proportion of radioactivity was found in the breath when ${ }^{14} \mathrm{C}$-labelled acetate or lactate was instilled into the caecum. It was therefore postulated that about $85 \%$ of the glucose was fermented to VFA which were absorbed and utilized by the host and about $15 \%$ were incorporated into a non-dialysable fraction, perhaps bacterial cell components. In the germ-free rats an 
Table 1. Sugars and volatile fatty acids (VFA) recovered in faecal water after feeding $146 \mathrm{mmol}$ raffinose (equivalent to $43^{8}$ mmol hexose)

\begin{tabular}{|c|c|c|}
\hline & \multicolumn{2}{|c|}{ Amount recovered } \\
\hline & $\mathrm{mmol}$ & $\begin{array}{l}\mathrm{mmol} \text { as } \\
\text { hexose }\end{array}$ \\
\hline \multicolumn{3}{|l|}{ Sugars found } \\
\hline Raffinose & $4^{6 \cdot I}$ & $138 \cdot 3$ \\
\hline Sucrose & $I \cdot I$ & $2 \cdot 2$ \\
\hline Melibiose & $27 \cdot 2$ & 54.4 \\
\hline Fructose & $28 \cdot 1$ & $28 \cdot 1$ \\
\hline Galactose & $40 \cdot 2$ & $40 \cdot 2$ \\
\hline Glucose & 5.9 & 5.9 \\
\hline Total & $148 \cdot 6$ & \\
\hline Hexose lost & & 169 \\
\hline VFA & $50 \cdot 2$ & - \\
\hline Lactate & 0.9 & - \\
\hline VFA expected & 287 & - \\
\hline
\end{tabular}

insignificant amount of ${ }^{14} \mathrm{CO}_{2}$ was found in the breath although the recovery when acetate was instilled was similar to that in conventional rats. The studies in humans gave essentially the same results and so did other studies on colonic utilization of sucrose in patients with malabsorption due to intestinal bypass operations for obesity (Bond $e t$ al. 1980 ). Limited amounts of NAS can therefore be assimilated into the animal body with only a small loss of energy content without causing diarrhoea.

When there is a larger intake of NAS other effects occur. The reason for the increased faecal output is still disputed but the coincidence of significant amounts of sugars in the faecal water at the time when increased output of faecal water occurs suggests the following mechanism (Saunders \& Wiggins, 1981): 'In the single dose experiments, we believe that diarrhoea ensued when the amount of soluble carbohydrate, and associated water and electrolytes exceeded the critical volume of the right colon and prompted colonic evacuation.'

\section{Continuous consumption of NAS}

Studies of the effects of continuous consumption of NAS have been very largely directed to the treatment of the abnormal $\mathrm{N}$ metabolism of severe liver disease. Some of the information that has been obtained is relevant to the present discussion. The aim in these studies is to feed enough NAS in divided doses to produce two or three semi-formed stools daily with approximately the same increase in faecal output for each member of the group. As Table 2 shows, there is a wide variation in the dose required to produce this effect in different individuals. The doses are similar to the threshold doses in the single-dose-response study and produce an average of about $100-300 \mathrm{~g} / \mathrm{d}$ increase in faecal output. It might cautiously be assumed that chronic ingestion can be considered as a series of single 
Table 2. Change $(g / d)$ in faecal outputs when non-absorbed sugars are given

\begin{tabular}{|c|c|c|c|c|c|c|c|}
\hline Sugar & $\begin{array}{c}\text { Threshold } \\
\text { dose }\end{array}$ & $\begin{array}{c}\text { Continuous } \\
\text { dose }\end{array}$ & $\begin{array}{l}\text { Increase } \\
\text { in wet wt }\end{array}$ & $\begin{array}{l}\text { Increase } \\
\text { in dry wt }\end{array}$ & $\begin{array}{c}\text { Increase in } \\
\text { nitrogen }\end{array}$ & $n$ & Source \\
\hline Lactulose & ${ }^{25-50^{\circ}}$ & $\begin{array}{l}40-80 \\
40-80\end{array}$ & $\begin{array}{l}185 \\
292\end{array}$ & $\begin{array}{l}22 \\
20.5\end{array}$ & $\begin{array}{l}0.9 \\
1.5\end{array}$ & $\begin{array}{l}5 \\
7\end{array}$ & $\begin{array}{l}\text { Weber \& Fresard (1981) } \\
\text { Weber (1979) }\end{array}$ \\
\hline & - & $30-50$ & 102 & - & - & 3) & \\
\hline Mannitol & $22-40^{*}$ & $10-50$ & 80 & - & -- & $3\}$ & Agostini et al. (1972) \\
\hline Sorbitol & - & $20-80$ & 90 & - & -- & 3] & \\
\hline
\end{tabular}

doses and that the same threshold phenomenon exists, although there is no direct evidence for this. What is clear is that at intakes from 20 to $80 \mathrm{~g} / \mathrm{d}$ increased faecal output occurs and this is accompanied by a decreased transit time.

In the normal state the colon absorbs as VFA or disperses as gases much of the dry matter that enters it through the ileo-caecal valve. For example, in a recent study patients with ileostomies produced $5^{8} \mathrm{~g}$ dry matter/d on a 'low-fibre' diet (Sandberg et al. 1983 ), whereas intact subjects on a diet somewhat higher in fibre produced only $22 \mathrm{~g} / \mathrm{d}$ (Cummings $e t$ al. 1979). When identical diets are eaten by normal individuals the faecal dry matter output is closely related to the transit time as is total $\mathrm{N}$ output (Figs. $\mathrm{I}$ and 2 ). Table 2 also shows that a substantial increase in faecal dry weight occurs when effective doses of NAS are given. It is not possible to say what proportion of this is the NAS or its products or is material that would normally have been absorbed in the colon but for the decreased transit time. There was also a substantial increase in the $\mathrm{N}$ output. When Debongnie \& Phillips (1978) infused an electrolyte solution that simulated ileal contents into the caecum at a rate of $4 \mathrm{l} / \mathrm{d}$ the dry matter in the stools increased from II to $32 \mathrm{~g} / \mathrm{d}$, although most of the extra electrolytes were absorbed. Taking these observations together it seems reasonable to assume that one of the effects of NAS in large doses is to decrease colonic salvage of the unabsorbed residues in the diet. Some of the loss of energy is compensated for by the extra energy absorbed from the NAS. The nutritional significance of the extra $\mathrm{N}$ loss depends on the chemical form in which it would have been absorbed from the colon. If some of it is absorbed as amino acids, as has been shown in the horse (Slade et al. 1971), it could increase the protein requirement to a small extent.

A consequence of the fermentation of NAS in the colon is a fall in the $\mathrm{pH}$ of the contents. This has been demonstrated by Bown et al. (1974) using a radiotelemetering capsule.

\section{Summary}

The nutritional consequences of the ingestion of NAS depend on the quantity ingested. At lower levels there is little effect on the absorption of other nutrients and the colonic microbiological-salvage mechanism operates and a substantial proportion of the energy is made available to the body through fermentation. The 


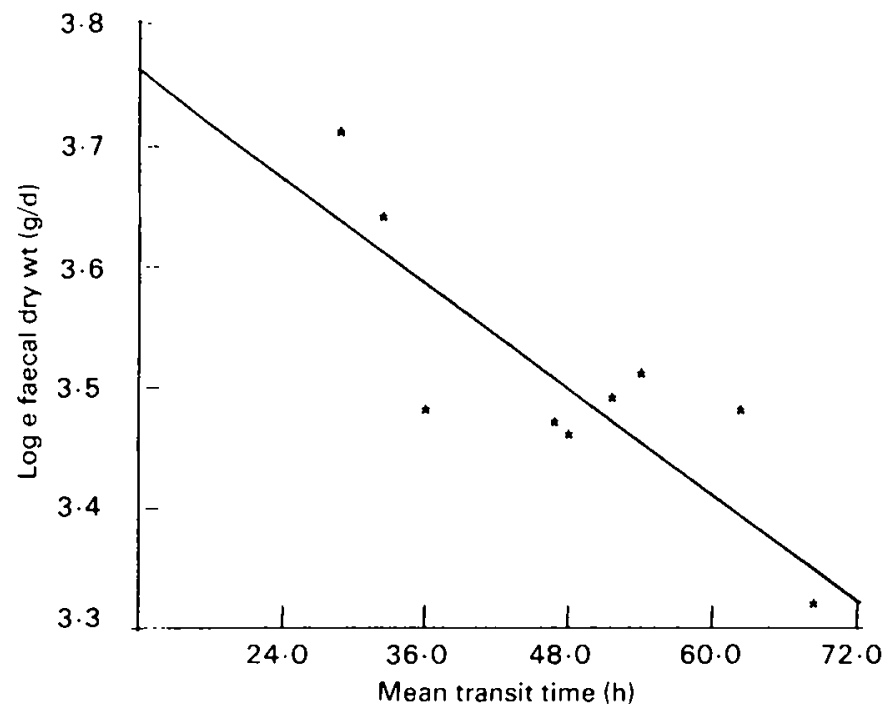

Fig. I. Relation of faecal dry weight to mean transit time for nine subjects eating identical constant diets. The range of dry weights was $27.6-41 \mathrm{~g} / \mathrm{d}$. The transit time was measured according to Cummings \& Wiggins (r975). The results are corrected by use of output marker (Branch \& Cummings, 1978) and are for the third week of the diet.

Regression: $Y=-0.007$ I $5 X+3.844, r 0.83$.

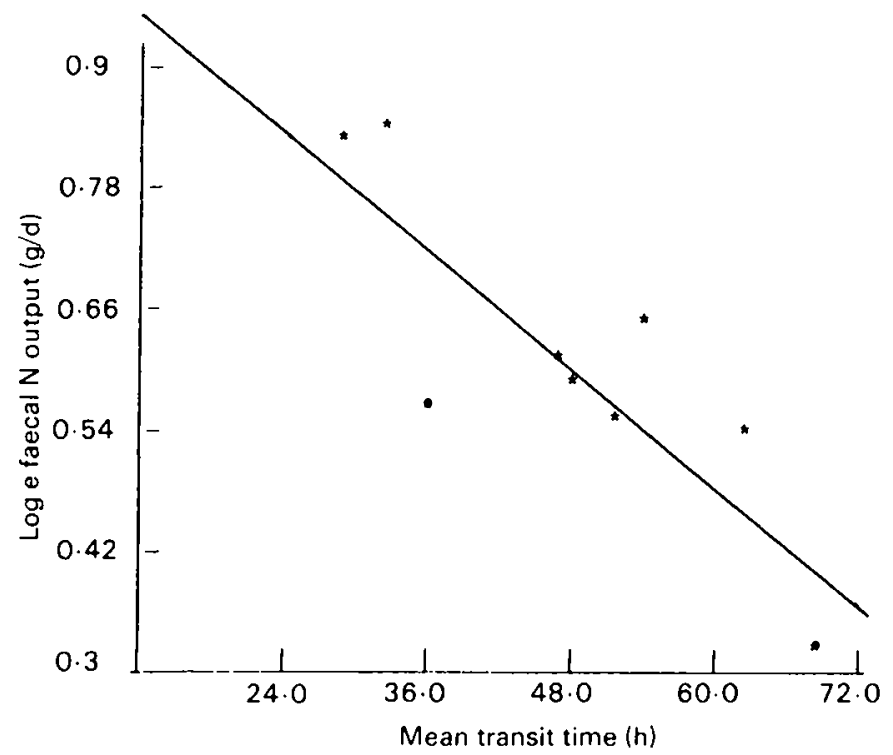

Fig. 2. Relation of faecal nitrogen to mean transit time for nine subjects eating identical constant diets. The range of $N$ outputs was $1.4-2.3 \mathrm{~g} / \mathrm{d}$. The transit time was measured according to Cummings \& Wiggins (1975). The results are corrected by use of output marker (Branch \& Cummings, 1978) and are for the third week of the diet.

Regression: $Y=-0.009929 X+1 \cdot 0837, r 0.84$. 
exact amounts that can be tolerated in this way vary for individuals and are different for different compounds. At higher levels of intake the capacity of the colonic digester is exceeded and the decreased transit time affects $\mathrm{N}$, energy, electrolyte and water metabolism. The responses to NAS are an example of how the animal body is dependent on the bacterial content of the colon to enable that organ to perform its function of water and electrolyte conservation.

\section{REFERENCES}

Agostini, L., Down, P. F., Murison, J. \& Wrong, O. M. (1972). Gut I3, 859-866.

Anderson, C. M., Messer, M., Townley, R. R. W. \& Freeman, M. (1963). Pediatrics 3I, ro03-1010.

Asano, T., Levitt, M. D. \& Goetz, F. C. (1972). Diabetes 2 I, 350-351.

Bond, J. H., Currier, B. E., Buchwald, H. \& Levitt, M. D. (1980). Gastroenterology 78, 444-447.

Bond, J. H. \& Levitt, M. D. (1976a). Gastroenterology 70, 1058-1062.

Bond, J. H. \& Levitt, M. D. (1 976b). Fournal of Clinical Investigation 57, I $158-1164$.

Bown, R., Gibson, J. A., Sladen, G. E., Hicks, B. \& Dawson, A. M. (1974). Gut 15, 999-1004.

Branch, W. J. \& Cummings, J. H. (1978). Gut 19, 371-376.

Cummings, J. H., Hill, M. J., Jivraj, T., Houston, H., Branch, W. J. \& Jenkins, D. J. A. (1979). American fournal of Clinical Nutrition 32, 2086-2093.

Cummings, J. H. \& Wiggins, H. S. (1975). Gut 17, 219-223.

Davis, G. R., Santa Ana, C. A., Morawski, S. G. \& Fordtran, J. (1980). Gastroenterology 78, $99 \mathrm{I}-995$.

Debongnie, J. C., Newcommer, A. D., McGill, D. B. \& Phillips, S. F. (1979). American fournal of Digestive Diseases 24, 225-231.

Debongnie, M. D. \& Phillips, S. F. (1978). Gastroenterology 74, 698-703.

Fordtran, J. \& Locklear, T. W. (1966). American Journal of Digestive Diseases II, 503-52 I.

Goldberg, N. J., Wingate, T. D., Levin, S. R. \& Adachi, R. 1. (1980). Gastroenterology 78, $1458-1462$.

Holdsworth, C. D. \& Dawson, A. M. (1965). Proceedings of the Society for Experimental Biology and Medicine I $18,142-145$.

Hungate, R. E. (1966). The Rumen and its Microbes. London: Academic Press.

Launiala, K. (I 669 ). Scandinavian fournal of Gastroenterology 4, 25-33.

Menzies, I. S. (1974). Biochemical Society Transactions 2, $1042-1046$.

Nasrullah, S. M. \& Iber, F. L. (1969). American Journal of Medical Science 250, 80-88.

Sandberg, A. G., Ahderinne, R., Andersson, H., Hallgren, B. \& Hulten, L. (1983). Human Nutrition: Clinical Nutrition $37 \mathrm{C}, 17 \mathrm{I}-183$.

Saunders, D. R. \& Wiggins, H. S. (1981). American fournal of Physiology 241, G397-G402.

Slade, L. M., Bishop, R., Morris, J. G. \& Robinson, D. W. (1971). British Veterinary Journal 1 27, xi.

Tauster, O. (1974). In Sugars in Nutrition, pp. 229-237 [L. H. Sipple and K. W. McNutt, editors]. London: Academic Press.

Weber, F. L. (1979). Gastroenterology 77, $518-523$.

Weber, F. L. \& Fresard, K. M. (1981). Gastroenterology 80, 994-998.

Wheeler, P. G., Menzies, 1. S. \& Creamer, B. (1978). Clinical Science and Molecular Medicine 54, 495-50r. 